\title{
EXPLORING HOW PERSONAL MENTORING ADDED VALUE TO BECOMING A HIGHER EDUCATION PRACTITIONER
}

\section{S. G. Makhanya}

Department of Community Extension

Mungosutho University of Technology and University of KwaZulu-Natal

Durban, South Africa

e-mail: siza@mut.ac.za

\section{ABSTRACT}

I explore personal mentoring that I received on my journey to becoming an experienced educator at a university of technology. The context of my personal mentoring was the community where I was born and grew up. I used bricolage method by combining autoethnography and personal history research methodologies. Living theory assisted me to appreciate how values from special mentors have inspired my professional growth and practice. I generated data by working with artefacts in the form of photographs and an object. I nominated my father, mother, community members, maternal and paternal grandmothers as my personal mentors. Composing and reflecting on my personal history narrative revealed values learned from personal mentoring, which were motivation, kindness, care and selflessness. These values learned from my family and community members played a significant part in my becoming an experienced practitioner at a university of technology.

Keywords: autoethnography, bricolage, personal history, living theory, personal mentoring, university educators, values

\section{INTRODUCTION}

I did not realise that interacting with my family and community members was training for the future. In this article, I make visible and reflect on the knowledge, values and skills gained from interacting with my family and community members. According to Bullough and Gitlin (1995), understanding oneself can involve understanding how one is influenced by events of the past as well as socio-historical moments and shared values. Zerzan et al. (2009) explained that "mentoring" can be created when people share the same interests. Furthermore Zellers, Howard and Barcic characterise mentoring as involving "trust, respect, and commitment" and sharing life experience for personal development $(2008,555)$. I discovered that mentoring is important for the transmission of information, values and skills to upcoming generations so that they can become prosperous in their future endeavours.

The aim of this article is to look at the personal mentoring that I contributed to my becoming an experienced higher education practitioner at a university of technology. In my 
searching about personal mentoring, I found no research on mentoring of higher education practitioners by family and community; this I understand to be part of personal mentoring. According to Anyangwe (2012), mentoring can demonstrate a personal relationship between parties.

This article builds on my master's research in which I examined whether I was living my values in my practice (Makhanya 2012). The results of this research indicate that I live my values in my practice, although there were challenges with the Clothing course I was teaching. The article forms part of my ongoing doctoral research, which is focused on my journey of becoming a higher education practitioner. In this article, I explore the concept of personal mentoring by considering how my family and members of the community, with whom I grew up, contributed to my development as a higher education practitioner. The research questions that have guided me in writing this article are:

1. How can I make visible personal mentoring that I received on my journey to becoming a higher education practitioner?

2. What values did I learn from the personal mentoring that I received on my journey to becoming a higher education practitioner?

\section{CONTEXT OF MY PERSONAL MENTORING}

The context of my personal mentoring occurred where I was born in Durban and lived with my family in Kwa-Mashu Township in the province of KwaZulu-Natal. Kwa-Mashu Township is close to the city of Durban. The township was erected in the 1960s under the apartheid Group Areas Act of the National Party government (eThekwini Municipality n.d.). The township has different units. I lived with my family in G Section, which is presently known as "Mgmara". $\mathrm{G}$ section is between $\mathrm{F}$ and $\mathrm{H}$ Sections. Most of the houses had either four rooms or two rooms but as the area developed, many people improved their houses. Presently, several houses look the same as the ones that are in the suburbs. People in the township come from different cultural backgrounds. Some are Zulu, Sotho, Xhosa, Venda and other South African ethic groups. These people interact with one another and learn from each other about the type of food, dress and other aspects of cultural heritage. When I was growing up, G section was busy and known for both positive and negative aspects. For example, one of the positive aspects was that a famous musician married someone from the section. A negative aspect was that sometimes fights happened and that people who were from other sections were mistreated. 


\section{CONTEXT OF MY WORK AS A HIGHER EDUCATION PRACTITIONER}

I am a higher education practitioner at a university of technology teaching Clothing, Nutrition, Health and Hygiene. I was first employed at the university of technology in 1996 as a contract lecturer. The university of technology where I am employed is in Umlazi township, which is the biggest township in KwaZulu-Natal (eThekwini Municipality n.d.). The university was erected to allow people to learn technical skills for vocational purposes. When there was a merger of universities this university did not merge with other universities.

The university caters for students who come largely from impoverished backgrounds. These students bring different knowledge and values to my practice as a higher education practitioner. Big companies have employed many of the young people who studied at the university. This motivates other young people to further their studies.

When I was first employed I had no experience in teaching in higher education, but with the assistance that I received from my colleagues, I learned about the requirements of being a practitioner at a university of technology. Mentorship is vital for academic achievement and career development (Carey and Weissman 2010, 1372). Now I am conducting doctoral research on personal and professional mentoring in my journey as a higher education practitioner. In this article, I focus specifically on personal mentoring that I have received.

\section{RESEARCH METHODOLOGY}

In writing this article, I used a bricolage method, which is described by Samaras et al. (2016) as a method combining different approaches to achieve the required goal. I combined autoethnography and personal history research approaches to explore the personal mentoring that I received on my journey to becoming an experienced higher education practitioner.

As Chang (2008) explains, "autoethnography is becoming a particularly useful and powerful tool for researchers and practitioners who deal with human relations in multicultural settings, such as educators". In my understanding, autoethnography involves connecting self and the group of people that we belong to who shape our behaviour by teaching us their values and their cultural heritage. According to Whitehead and Fitzgerald (2007), it is important to have a desire to demonstrate values in our practices as educators. In composing a narrative about the community where I was born, I selected amazing personal mentors whose values I have applied in becoming an experienced higher education practitioner. Ellis, Adams and Bochner (2011) describe autoethnographic writing as a method where the author selects and reflects on past experiences in order to understand some aspects of culture; I am explaining my values and beliefs as vital parts of my cultural heritage. As Ellis (2007) explains, this helped to keep remembrances. Writing an autoethnographic narrative also helped me to share my 
memories and my learning about personal mentoring with others because autoethnography is intended to be written in reader-friendly way that engages readers (Chang 2008).

According to Chang (2008), autoethnographic studies frequently cover emotive topics, including those conventionally kept private, such as mother-daughter relationships. I nominated people whom I consider as my personal mentors to be included in my autoethnographic narrative. I included my father, mother, maternal grandmother and paternal grandmother because I consider them as my personal mentors. As Zerzan et al. $(2009,142)$ reminded me, "mentors are people who have impacted positively on our lives". Hamilton, Smith, and Worthington (2008) explain that reflection and reflexivity contribute to trustworthiness in self-focused methodologies such as autoethnography. I also requested that my sister read my writing on my personal history of becoming a higher education practitioner. Having somebody who knows about my personal mentors read my narrative contributed to trustworthiness of the article.

Samaras, Hicks and Berger $(2004,909)$ refer to personal history as "those formative, contextualized experiences that have influenced teachers' thinking about teaching and their own practice". They go on to explain personal history research "as the historical or life experiences related to personal and professional meaning making for teachers and researchers". In reflecting on my personal history, I realise that knowledge, skills and values that I learned from interacting with family and community members have added value to my becoming an experienced higher education practitioner. In order to make visible their personal mentoring, I reflected on the outcomes of my interaction with personal mentors in order to understand the values that I learned from them.

I also collected photographs in order to make visible and understand how these personal mentors influenced my life. In addition, I used an object to understand the educational meaning of one of my personal mentors. Chang $(2008,125)$ advises, "autoethnographic data analysis and interpretation involve shifting your attention back and forth between self and others, the personal and the social context". To shift my attention in this way, I followed Samaras' (2011) method of analysing my visual artefacts through responding to a series of self-reflexive writing prompts (see Samaras 2011, 105). The visual data worked hand in hand with my writing because responding to these prompts enabled me to examine these artefacts to understand better what was happening in my life when I interacted with my family and community members (Chang 2008).

\section{RELATIONAL ETHICS}

Autoethnographers interact with people who offer ideas for writing our narratives about 
personal experiences. Ellis (2007) sees relational ethics as a difficult focus for authoethnographers. She explains that it is important that "autoethnographic narratives do not reflect negatively on the person who is writing the narrative or those featured in the narrative" (Ellis 2007, 16). I followed the ethical procedure in order to protect the people who were mentioned in my narrative writing. I requested permission from my siblings in order to write about the personal mentoring that I received from my family. Having my sister read my narrative also contributed to the relational ethics of my research. Some of the community members that I mention in my narrative are not alive; however, I received the consent from someone who was my friend at that time.

\section{LIVING THEORY}

According to Whitehead (2005), a living theory is an explanation of learning in relation to the values that help to make one's life meaningful and purposeful. Whitehead (2005) continues by explaining how the meanings of one's values can be clarified by considering how they emerge in practice and, through this process, values can be transformed into living standards of judgment that can be used to evaluate a claim to knowledge. My living theory is embedded in the values of care, kindness and selflessness, which I bring in my practice in order to clarify personal mentoring that I influenced my becoming an experienced higher education practitioner (Mcniff and Whitehead 2002).

\section{MY FAMILY MENTORING}

In my view, family mentoring can occur when people live together as family or friends. When I was young child, I was fortunate to live with both my father and mother and my siblings. They guided me in what I should do and not do. It was not always easy to accept my family's instructions because when I interacted with my peers they would view my opinions as irrational, but today I value those instructions from my family. An example is that after school I would go straight home and not to play with my friends. I now interpret my parents' guidance as personal mentoring. The personal mentoring that I received from them was significant in my becoming an experienced higher education practitioner.

According to Awaya et al. (2003), mentoring is a relationship that can be personal and there is a choice to accept or not accept what is being taught. I value what I was taught by my personal mentors and consider the values of kindness, care, selflessness and motivation as inspiring gifts, which I must transfer to the next generation. I wrote my family personal history narrative guided by Chang $(2008,32)$ who described autoethnography as related to a method that is used by "anthropologists to explore life histories of their family members". In my 
narrative, I consider my father, mother, maternal grandmother and paternal grandmother as people who personally mentored me with values that have been significant in my becoming an experienced higher education practitioner. Simon as (cited in Schulze 2009,117) explains that "mentoring is not just a means of achieving goals but can also be an expression of Christian virtues, especially practical, wisdom, love, hospitality, conviction and humility". I will start by discussing my father's mentoring.

\section{My father's mentoring}

The personal mentoring that I received from my father happened for only a few years because my father passed away when I was ten years old. I remember how my siblings and I would sit with my father at night. We discussed our future careers, which I now realise motivated me to study. According to Anyangwe (2012), every mentoring relationship is distinctive. I remember the distinctive relationship that I had with my father because of the motivation that I gained from interacting with him. My father and his colleagues see Figure 1.

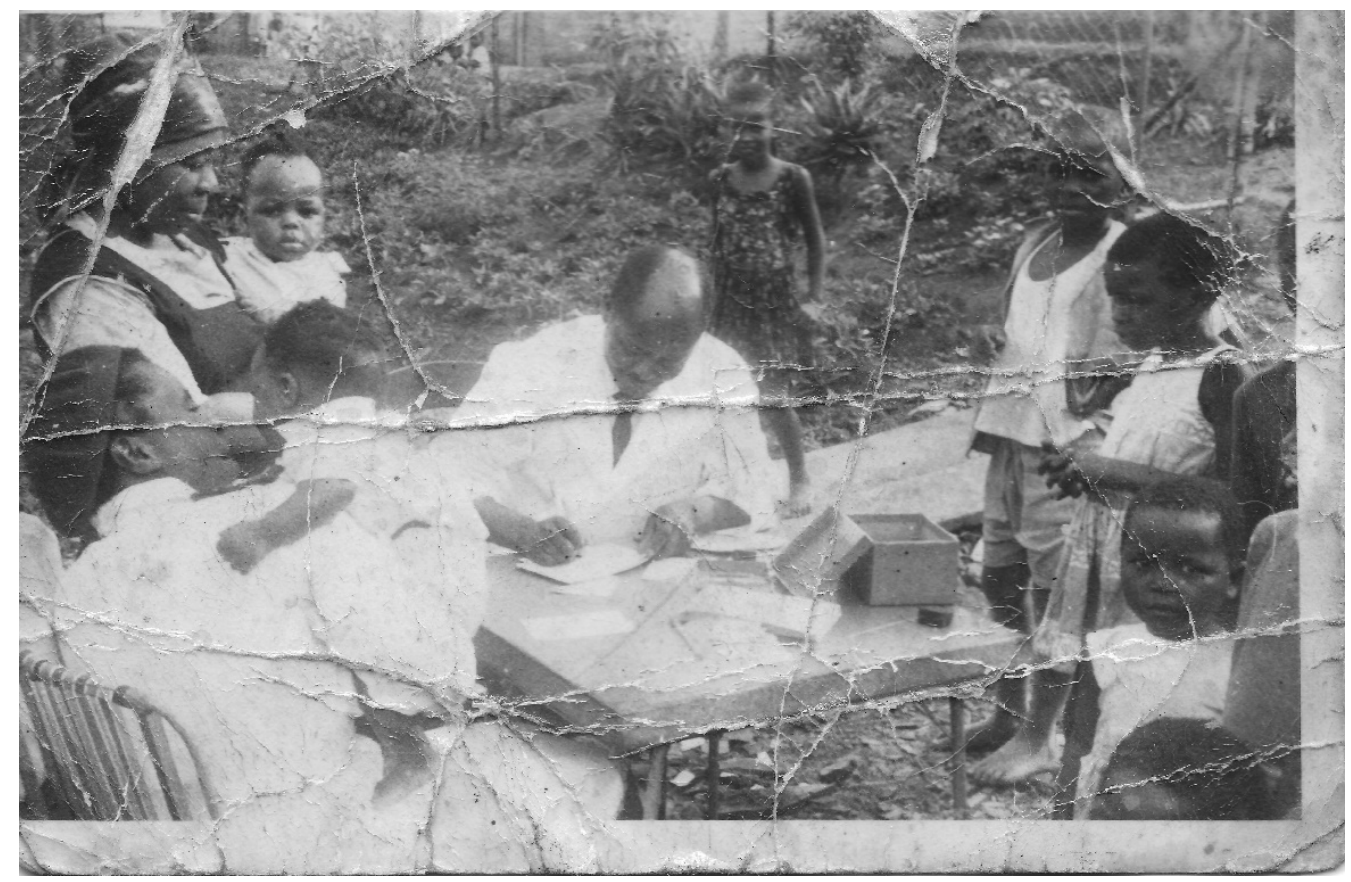

Figure1: A photograph of my father and his Department of Health colleagues working with the community

I chose the photograph because it takes me back to memories of my father who motivated and inspired me. In my research, the visual artefact of the photograph represents mentoring that contributed to my becoming an experienced higher education practitioner. The artefact also helps me to recall my teachers and classmates at lower primary school. The Department of 
Health at that time would send health workers to schools to check whether the learners had been vaccinated to protect them from diseases. In the photograph, my father is shown seated at a table, writing. My father was one of those health workers and this motivated me to desire to become a nurse. My early dream to be a nurse did not materialise; but I ended up becoming a higher education practitioner. I see this as a form of community service, which can contribute to social change.

There is a special object that has been around at home since I was a child. The object is a dessert bowl. I was told by my mother that when she met my father he placed a set of bowls in his room. There were originally six dessert bowls, but only two remain. One of the bowls is depicted in Figure 2.

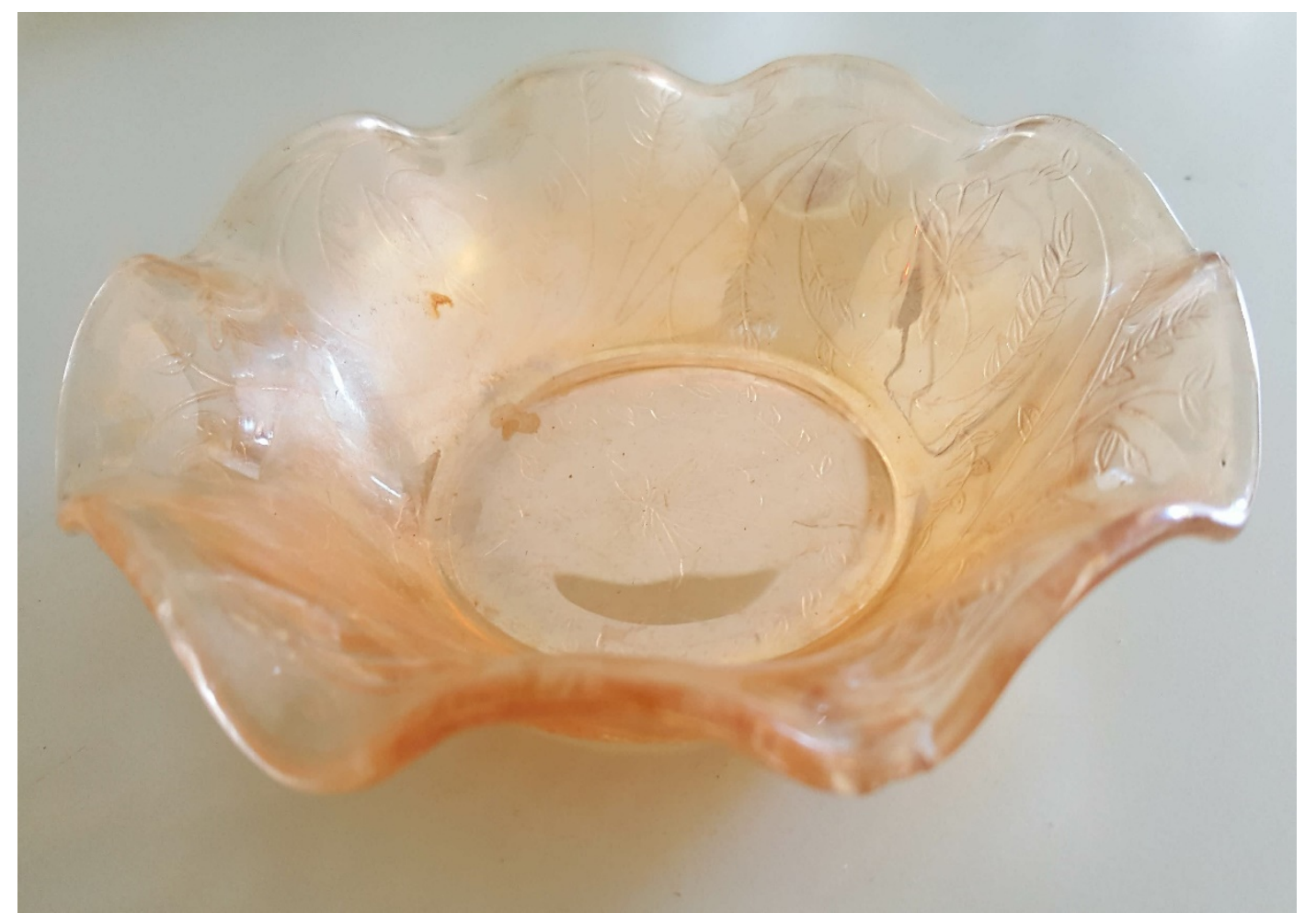

Figure 2. The dessert bowl: An object that represents my father's mentoring

As explained by Riggins (1994), object mapping means looking at the way in which an object serves as a means of eliciting a story. The dessert bowl is made of glass and has designs that appear as curves on the sides. I interpret these curves as a symbol of the world that is round and it stays the same while it is what is inside that changes. When we moved from one place to the other, we travelled with my father's bowls. When we had family gatherings, we used the bowls and relatives knew the bowls. This bowl holds memories of what happened in the family and it has been with us through generations. 
The bowl as an object in my research reflects guidance and values that I received on my journey, culminating in being an experienced higher education practitioner. The value that I can associate with this object is motivation to do my best in order to survive. It is a pity that my father, who bought the object in our family, is not around to explain its meaning to us. However, I can interpret that he bought the set of bowls because he had a dream of having a family. The photograph of my father (Figure 1) signifies to me that my father, the original owner of the dessert bowl, cared not only for his family but also for other families because in the photograph there is a woman holding a baby. Maybe the woman and the baby reminded him of his family.

\section{My mother's mentoring}

When contemplating my relationship with my mother, I see her as a personal mentor because she guided me when I was young. I will start by "walking down memory lane" to tell my story of my mother's personal mentoring (Masinga 2012, 123). I recollect how, when I was a young girl, my mother would often accompany me. My friends would even enquire why I was constantly with my mother. When I was studying at a university outside my home province, my friends knew that my mother would be waiting for me at the station when we came back for holidays. I see now that this was evidence of the value of caring even though I was actually old enough to travel alone.

Because my mother was interested in gardening, we had a flower garden. When flowers blossomed, we would take them to church and give them to women who lived nearby. I recall the golden colour of those flowers. I also recollect how we would go and call on my grandmother and when she was sick we would go and care for her. As Harrison et al. (2012, 17) explain, "Ubuntu is awareness and acknowledgment of other people's life courses". When I reflect on my mother's personal mentoring, I consider it as being guided by Ubuntu. Ubuntu motivates a person to care for and respect the existence of other people.

My favourite memory of the personal mentoring that I received from my mother took place at Christmas. We would leave early in the morning to do our shopping. Something I remember about the shopping is searching for shoes the whole day and still not finding shoes were suitable. I think from that I learned something, which helped me in the Clothing course that I am teaching at a university of technology. There were changes when my father passed away as we were obliged to wear whatever was given to us. In this case, I had to be satisfied with old shoes.

As I mentioned, I did not spend much time with my father because he passed away when we were young. In my experience, if a woman lost her husband at an early age, she might decide to remarry and leave her children behind; however, my mother decided to work hard to provide 
for the family. I can see how that motivated me to work hard to succeed in what we were doing. That also helped in transferring the value she placed on caring for us in a manner that she desired. Whitehead $(1989,47)$ describes values as "living standards of judgment" that can be expended to assess what is accepted by people with whom we interact in the environment.

A value that emerged from my mothers' personal mentoring was kindness. When my father passed away, relatives demonstrated kindness by helping with our education. I recall how my relatives would come and visit us during the holidays. When they came to visit us they would bring something which we could all share as a family. I consider that as kindness, which I learned and I now offer assistance when it is needed. These values "resonated with understanding of what is right or not" (Wood 2014, 44). The value of kindness is a guiding light for me as it was very much part of my personal mentoring.

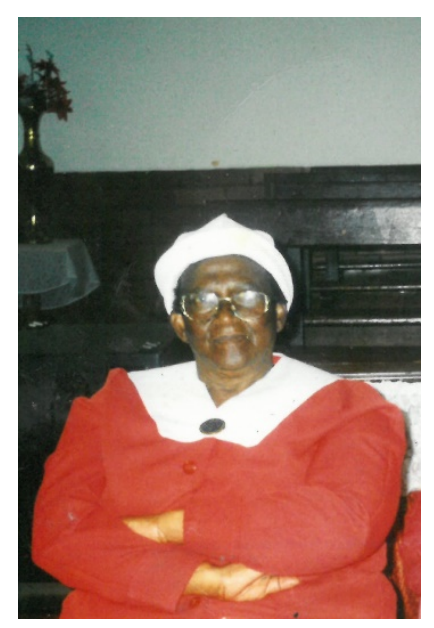

Figure 3: A photograph of my mother wearing Methodist church uniform

My mother is shown wearing the Methodist church uniform in Figure 3. I chose the photograph because, as Samaras (2011) explains, using visual artefacts such as photographs can improve understanding of our research interests. For me, the artefact of the photograph represents the values of caring and kindness that I learned from my mother. I consider part of my mother's personal mentoring was care because she had the desire to help members of the Methodist church by providing assistance when they were sick or lost their loved ones. I remember that as children, lack of understanding of what our mother she was doing would lead us to complain that she did not stay at home enough and that she was always travelling. However, now I see the artefact plays a very important role in demonstrating the need for each other as human beings.

The community where I was born is reflected in the artefact because it is about my mother's work. Schulze (2009) explains that personal identity is different for each individual 
and that explaining this provides them with a chance to share personal stories. It also provides social identity: knowing that my mother once belonged to a group of people. The church community gave my mother a chance to interact with their families and provide them with support when they desperately needed it. It also provided me with a chance to gain personal mentoring, which is more significant now when I look back and feel proud about what she was doing for the community.

The values of care and kindness that I learned from my mother are adding value to my practice as a higher education practitioner. For example, sometimes students have to be mentored to treat other students with caring and kindness, especially when they do presentations for the first time. Mentoring the students on the values of kindness and care helps me to evaluate if I am living up to my own standards in my teaching.

\section{My maternal grandmother's mentoring}

My maternal grandmother was MaNdlovu. She lived with her family in Richmond. I believe that she had 11 children. I recall what my grandmother looked like because I encountered her several times before she passed on. I remember her attending a church conference. We went to see her in one of the townships near Durban. She was wearing a Methodist woman's Manyano uniform. I searched for a photograph of her but was unable to find one. I then decided to use a photograph of a group of women wearing the uniform (Figure 4). What I know about the photograph is that it was taken when my mother attended meetings.

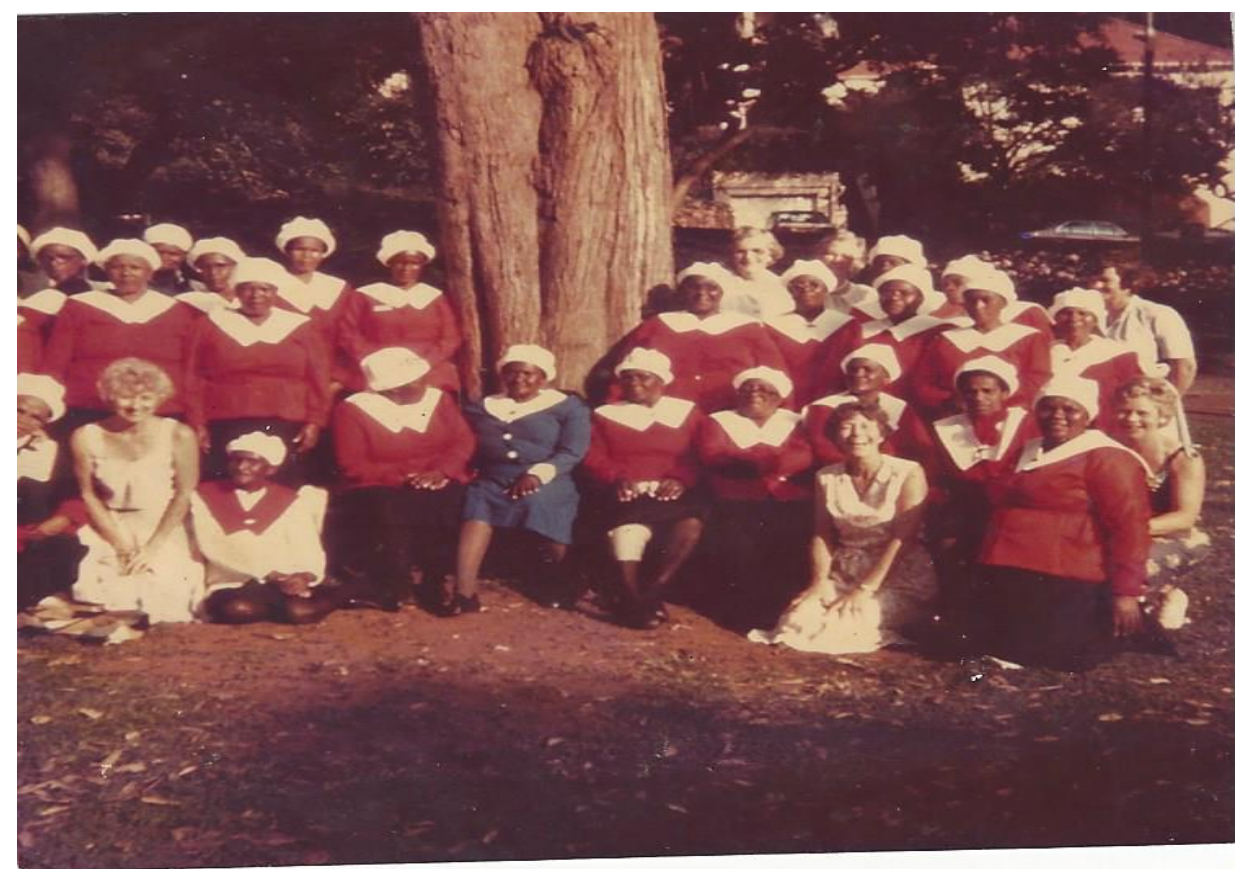

Figure 4: A photograph of a Manyano, which is a group of praying women who belong to the Methodist church. 
I chose the photograph of women wearing the Methodist church uniform because my grandmother transferred her value of selflessness to my mother. My mother was taught particular values by my grandmother. My mother conveyed those values to us as her children. The visual artefact of the photograph represents how personal mentoring about the value of selflessness was transmitted from generation to generation. My grandmother encouraged my mother and her siblings to "explore attitudes, expectations, and activities that are worth adopting" (Anyangwe 2012, 2). To me, the photograph of women in church uniform represents the passion with which my grandmother mentored the next generations regarding direction that they must follow. In my personal culture, the photograph epitomises how the value of selflessness is transferred from one generation to the next generation.

\section{My paternal grandmother's mentoring}

I remember that in 1997, we were told by one of my relatives that we must buy a book called "The calling of Katie" by Margaret McCord (1995). The book was about the biography of my paternal grandmother. My paternal grandmother wanted the future generations to know what was happening during her lifetime and be motivated to extend their dreams.

It was after reading Katie's published biography that I understood more about her. I was named after my grandmother, Katie, so her spirit would continue living and my younger sister was named Charlotte after Katie's older sister. Katie's' surname was Manya; she was a Pedi woman who came to KwaZulu-Natal to marry Ndeya, my grandfather. I read in her biography that my grandfather was visiting Johannesburg and saw this beautiful Pedi woman and decided to go back to Johannesburg the following week to ask her to marry him.

Katie assisted others around her who were ill. That demonstrates selflessness because she would leave her family to help others. I concur with Schulze (2009) who explains that adding value to others' lives to influence forthcoming generations is a vital mission for mentors. The value of selflessness is thus part of personal mentoring from my paternal grandmother.

\section{Mentoring that I received in the community where I grew up}

I can identify different types of personal mentoring in the township where I was born. In my understanding, personal mentoring can come from family, neighbours, peers and it can also be street mentoring. In my master's thesis (Makhanya, 2012) I explained that among the values instilled in my youth, I recall, in particular, the principle that requires that all adults be treated with the same respect as one's parents. On each street corner in the township there were people who would always provide personal mentoring. I see this is a form of public pedagogy. 
According to Sandlin, O’Malley and Burdick (2011), public pedagogy can be described as education beyond formal schooling.

One example of personal mentoring that I received in my community was from a woman who was a florist. I used to call on her because I was fascinated by learning about flower arranging. She taught me how to display flowers and when she was doing arrangements for functions such as weddings, she would ask me to accompany her to learn more. From this, I learned about flower arranging and I taught this to students at the beginning of my career. As stated by Sambunjak and Marusic (2009), mentors help others to obtain and assimilate new learning to attain professional development. When I reflect about the florist's personal mentoring, I can say it was part of my motivation in becoming an experienced higher education practitioner.

When reflecting about my journey as a higher education practitioner, I discovered that the personal mentoring that I received contributed greatly to my career. I was able to use the skills learned from community members to teach my students. According to Sorcinelli and Yun (2007), mentoring can increase networking opportunities. I also discovered that being a higher education practitioner is an extension of what my personal mentors were doing. Teaching Clothing at a university of technology is the extension of my mother's value of care to cater for her family and people who are interested in sewing. Care was demonstrated by teaching the unemployed people sewing skills, which changed their lives for the better.

Another example of personal mentoring which contributed to my becoming a higher education practitioner was from a neighbour who was the matron at the clinic where I was first employed. When she saw me walking with my friends on the streets, she would call me and ask the same question all the time. The question was, "Tell me how long you are going to be an assistant?" I ended up taking cover whenever she came past because she would always ask the same question. I would deliberate about what she said with my friends; but I found it difficult to understand her question. However, I later understood that she was striving to inspire me to study further. I now appreciate her motivation.

An example of mentoring that I received from my peers was from a friend who was employed at the civic offices. My friend told me that one of our schoolmates was now at university in Cape Town. She asked her to tell others to study at the university. I applied but I was not able to go since I was pregnant. Nevertheless, with her motivation, I started my studies the following year after I had given birth to a baby girl called Nomfundo because I had desire to be an academic.

I also received personal mentoring at my church. There was a woman who was responsible for teaching young women about faith and selflessness. She met after each church service with 
a group of young women. She taught us about reading the Bible and prayer. Through those meetings, we learned how to pray and fear God. We appreciated those meetings because even if she disciplined us she would do it in a courteous manner. Later on, when we reflected back with other group members, we discovered that those classes contributed in our lives. We are still serving the Lord.

\section{ANALYSIS OF THE SIGNIFICANCE OF VALUES LEARNED FROM PERSONAL MENTORING}

As illustrated in the previous sections, the values that I learned from personal mentoring were motivation, kindness, care, and selflessness. These values have remained central to my ontology, and have contributed to my becoming an experienced higher education practitioner. I discovered that personal mentoring helps me to deal with students at the university of technology. Sometimes it is challenging to deal with students and higher education practitioners need to be able to deal with them without being in conflict with one's values. Students are easily influenced by their peers and they also experience challenges. When writing about my lived experience of becoming an experienced higher education practitioner. I discovered that in my practice I bring values learned from personal mentoring. When reflecting on these values I discovered that they were related to one another. In my being a higher education practitioner, I have to use all the values that I have in order to improve what I am doing.

The values that I gained from my personal mentors provide me with the strength to continue teaching even when I encounter challenges and the energy that flows from these values reminds me of personal mentors. I have learned that a relationship with the students is influenced by how they are treated; which raises the importance of the values of kindness, care and selflessness and motivation. Whitehead (2009) describes values as tools that give meaning to energy flowing in education. Figure 5 is a visual example of how energy flows from me to students.

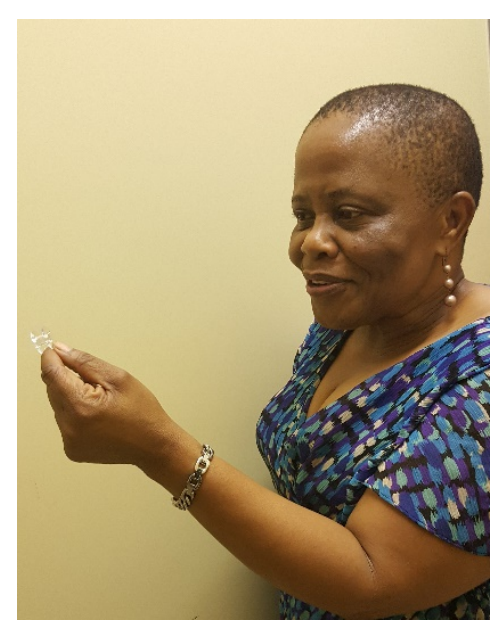

Figure 5: Demonstrating the flow of energy by winding the bobbin 
The photograph in Figure 5 demonstrates how I teach students to thread the bobbin for the sewing machine in my Clothing class. The photograph demonstrates the flow of energy from me to students (Whitehead, 2009). These values of care, kindness, selflessness and motivation provide the flow of energy when interacting with students in my practice and yield creativity, inspiration and passion for the course that I am teaching.

I have also discovered that the energy flowing from my values provides me with the love of what I am doing in my educational practice. This results in passion to learn and improve what I am doing. Awareness of values encompassing kindness, care, selflessness and motivation help me in evaluating my educational influence to understand if I am living my values in my practice (Whitehead 1989). It also assists in questioning whether I am transferring those values to my students.

Clarification of my values provided understanding of how personal mentors played a role in my becoming a higher education practitioner. When clarifying my values, I discovered that there are values that I learned while growing up as a Kwa-Mashu township girl. The values acquired from personal mentoring are part of my value system. Although in my journey as a higher education practitioner I have encountered situations which have forced me to protect myself, I remember where I come from, as the values of kindness, care, selflessness and motivation have helped me to survive.

My interest in understanding whether or not I am living my values started in 2010 when I registered for my master's degree in order to explore how I could improve teaching and learning in a clothing class at a university of technology (Makhanya, 2012). Autoethnographic research helped me understand the origin of my values. This motivated me to further my studies. Through my doctoral research, I have discovered that mentoring does not occur only at a professional level but it also occurs at the level when we interact with our families and community members.

Motivation to succeed in what I am doing forms part of the values that I learned from my personal mentors. Elliot and Covington (2001) define motivation as a hypothetical concept that is used to define people's behaviours and needs. Motivation plays an important role in doing the job of a higher education practitioner. I concur with Wigfield et al. (2004) that motivated students are likely to engage in a task willingly, as well as work to improve their skills, which will then increase their capabilities and chances of employment. For impoverished students, this can change their lives and the lives of their families and communities.

The value of motivation to study is still operating in me as I have the desire to further my studies even though I am working. In my practice, I am motivated to work with the students 
and not be afraid to learn about new teaching methods that can improve my practice. I am always motivated to attend workshops and conferences to learn about new approaches that can be used to improve teaching. Success in my career as a higher education practitioner is influenced by motivation I learned from personal mentoring.

The values of kindness, selflessness and care are all controlled by motivation. The photograph of the bowl that is depicted in Figure 2 demonstrates how the motivation of my personal mentor (my father) helped to improve his life. To me, this photograph means that every day a person must be motivated to work hard to achieve dreams that will add value to life in the future.

The values extend to my practice; an example can be the analysis of a student's narrative in my clothing practical class. In my Master's thesis (Makhanya, 2012), I describe a student who submitted work of high quality after being given assistance. She was struggling with sewing and so I did all my best to assist her. I also allocated time so that I could assist her with her sewing after classes. I used to be concerned about her struggling with sewing. I gave her extra classes to finish her projects and over time this student developed creativity. The student developed the value of creativity while I brought my own values of motivation, kindness, care and selflessness, which helped her to succeed in her studies. Mentoring the student represents the values that I learned prior to being a higher education practitioner.

The transfer of sewing skills to students and other people who are interested in learning is an extension of the values that I leaned from personal mentoring. Transferring sewing skills is part of kindness, which is feeling of what other human beings are experiencing. Selflessness and care are values that are part of my value system when observing other human beings improve their life.

\section{CONCLUSION}

In this article, I used a bricolage research approach to explore the personal mentoring that I received. Using a bricolage method helped me to discern how values that I received from my personal mentors have come together as a kind of collage that serves as a blueprint for my educational practice.

Combining autoethnography and personal history research methodologies with living theory helped me to understand how personal mentoring is transferred from one generation to the next generation in the interests of personal and social change. Exploring my life stories and personal mentoring that I received in my life helped me to discover new truths that I might have ignored before (Bullough, 1994). In order make visible and clarify personal mentoring that I received I looked at personal mentoring from my mother, father paternal, maternal 
grandmothers and community members. I explained how each mentor transferred certain values that assisted me on my journey to becoming an experienced higher education practitioner.

I agree with Cunningham (as cited in Schulze 2009) who clarifies how mentors influence the next generation in a positive manner. In this article, I have articulated a story of how I am growing a new knowledge of personal mentoring. My learning about how personal mentoring has influenced my own growth as a higher education practitioner inspires my living educational theory (Whitehead 1989). This new understanding is important, not only for my own learning, but also for other practitioners who might benefit from an enhanced awareness of the significance of personal mentoring. I am explaining my educational inspiration in my own learning, in the learning of others and in the connection of social formations through research (Whitehead 2005). I am trying to fulfil my aspirations for a better society through education as I add new ideas and new practices of personal mentoring.

\section{REFERENCES}

Awaya, A., H. Mcewan, D. Heylerb, S. Limsky, D. Lum and P. Wakukawa. 2003. Mentoring as a journey. Teaching and Teacher Education 19: 45-56.

Anyangwe, E. 2012. Mentoring: Building relationships that benefit academic careers. The Guardian. http://www.theguardian.com/higher-education-network/blog/2012/aug/08/mentoring-highereducation-careers (Accessed from Higher Education Network website).

Bullough Jr., R. V. 1994. Personal history and teaching metaphors: A self-study of teaching as conversation. Teacher Education Quarterly 21(1): 107-120.

Bullough, R. V. and A. D. Gitlin. 1995. Becoming a student of teaching: Methodologies for exploring self and school context. New York: Garland.

Carey, E. C. and D. E. Weissman. 2010. Understanding and finding mentorship: A review for junior faculty. Journal of Palliative Medicine 13(11): 1371-1379.

Chang, H. 2008. Autoethnography as method. Walnut Creek, CA. Left Coast Press.

Ellis, C. 2007. Telling secrets, revealing lives: Relational ethics in research with intimate others. Qualitative Inquiry 13(1): 3-29.

Ellis, C., T. E. Adams and A. P. Bochner. 2011. Autoethnography: An overview. Forum: Qualitative Social Research 12(1): 1-18.

Elliot, A. J. and M. V. Covington. 2001. Approach and avoidance motivation. Educational Psychology Review 13(2): 73-92.

eThekwini Municipality. n.d. Introduction to our town. http://www.durban.gov.za/Discover_Durban/ History_Communities/Our_Town/Pages/Introduction_to_Our_Town.aspx (Accessed 28 September 2016).

Hamilton, M. L., L. Smith and K. Worthington. 2008. Fitting the methodology with the research: An exploration of narrative, self-study and autoethnography. Studying Teacher Education 4(1): 1728.

Harrison, L., K. Pithouse-Morgan, J. Connolly and T. Meyiwa. 2012. Learning from the first year of the Transformative Education/al Studies (TES) project. Alternation 19(2): 12-37.

Makhanya, S. 2012. Improving teaching and learning in a clothing class at a university of technology. Unpublished MEd Dissertation. Walter Sisulu University, Umtata. 
Masinga, L. 2012. Journeys to self-knowledge: Methodological reflections on using memory-work in a participatory study of teachers as sexuality educators. Journal of Education 54: 121-137.

McCord, M. 1995. The calling of Katie Makanya: A memoir of South Africa. New York: John Wiley and Sons.

Mcniff, J. and J. Whitehead. 2002. Action research: Principles and practice. $2^{\text {nd }}$ Edition. London: Routledge.

Riggins, S. 1994. Fieldwork in the living room: An autoethnographic essay. In The socialness of things: Essays on the socio-semiotics of objects, ed. S. Riggins, 101-147. Berlin: Moutin de Gruyter.

Samaras, A. P. 2011. Self-study teacher research: Improving your practice through collaborative inquiry. Thousand Oaks, CA: Sage.

Samaras, A. P., M. A. Hicks and J. G Berger. 2004. Self-study through personal history. In International handbook of self-study of teaching and teacher education practices, ed. J. J. Loughran, M. L. Hamilton, V. K. LaBoskey and T. Russell, 905-942, Vol. 2. Dordrecht, Boston; London: Kluwer Academic Publishers.

Samaras, A., K. Pithouse-Morgan, T. Chisanga, J. Conolly, L. S. Constantine, T. Meyiwa and D. N. Timm. 2016. Networkism: Transcontinental dialoguing about co-facilitating transdisciplinary self-study professional learning communities. In Enacting self-study as methodology for professional inquiry, Self-study of teacher education practices (S-STEP), ed. D. Garbett and A. Ovens, 163-170. Herstmonceux, UK. https://dl.dropboxusercontent.com/u/94210171/Enacting 20self 20study.pdf

Sambunjak, D. and A. Marusic. 2009. Mentoring: What's in a name? Journal of the American Medical Association (JAMA) 302(23): 2591-2592.

Sandlin, J. A., M. P. O'Malley and J. Burdick. 2011. Mapping the complexity of public pedagogy scholarship 1894-2010. Review of Educational Research 81(3): 338-375.

Schulze, S. 2009. Mentoring novice researchers in higher education: A "communities of practice" perspective: Research article. Koers: Bulletin for Christian Scholarship 74(1-2): 117-137.

Sorcinelli, M. D. and J. Yun. 2007. From mentor to mentoring networks: Mentoring in the new academy. Change, November/December: 58-61.

Whitehead, J. 1989. Creating a living educational theory from questions of the kind, "How do I improve my practice?" Cambridge Journal of Education 19(1): 41-52.

Whitehead, J. 2005. "Living critical standards of judgment in educational theorising". A paper presented to a Symposium on "Creating and Testing Inclusional and Postcolonial Living Educational Theories" at the 2005 Conference of the British Educational Research Association, University of Glamorgan, 15th September 2005. http://jackwhitehead.com/bera05all/ jwbera05pap.htm (Accessed 1 August 2015).

Whitehead, J. 2009. An epistemological transformation in what counts as educational knowledge: Response to Laidlaw and Adler Collins. Research Intelligence: 488 and 106.

Whitehead, J. and B. Fitzgerald. 2007. Experiencing and evidencing learning through self-study: New ways of working with mentors and trainees in a training school partnership. Teaching and Teacher Education 23: 1-12.

Wood, L. 2014. Values based self-reflexive research action research for promoting gender equity. Some unexpected lessons. Perspectives in Education 32(2): 37-53.

Wigfield, A., J. T. Guthrie, S. Tonks and K. C. Perencevich. 2004. Children's motivation for reading: Domain specificity and instructional influences. Journal of Educational Research 97: 299-309.

Zellers, D. F., V. M. Howard and M. A. Barcic. 2008. Faculty mentoring programs: Re-envisioning rather than reinventing the wheel. Review of Educational Research 78(3): 552-588.

Zerzan, J. T., R. Hess, E. Schur, R. S. Phillips and N. Rigotti. 2009. Making the most of mentors: A guide for mentees. Academic Medicine 84(10): 140-144. 